\title{
P3093
}

\section{労働者の健康情報の取扱いについての産業保健専門職の意識と 個人情報保護法への対応}

\author{
堀江 正知、筒井 隆夫、永野 千景、佐々木直子、川瀬 洋平 \\ 産業医科大学産業生態科学研究所産業保健管理学
}

【目的】 2005 年 4 月に個人情報保護法が全面施行さ れ、関係する行政ガイドラインも示され、企業、健 康保険組合、労衝衛生機関診断などは個人情報取 扱事業者としての義務を遵守しなければならなく なった。労働者の健康情報に関しては、国際的な倫 理指針が医療職による一切の取扱いを求めている が、労衝安全衛生法は事業者による保存を求めて いる。そこで、本研究は、産業保健専門職の現行法 に対する意識掞よびその担当事業場における個人 情報保護法への対応の状況を調べる目的で実施し た。

【方法】 2005 年 5 月から 8 月に東京、千葉、大阪、 京都、広島、福岡の 6 都市で 8 回開催された産業保 健の專門職および担当者を対象とした研修会の前 に、A4 版 1 ページで作成した健康情報の取扱いに 関する多肢選択方式で無記名式の質問紙を合計 423 人に配布し、直接提出させた。

【結果】 354 人から有効回答があった（回答率 $83.7 \%$ ）。回答者は、医師 3 人、保健師 156 人、看 護師 131 人、その他の健康管理担当者 57 人であっ た。労働者の健康情報は、人事担当者がみるべきで ないという意見は 110 人 $(31.3 \%) 、$ あ程度は見る

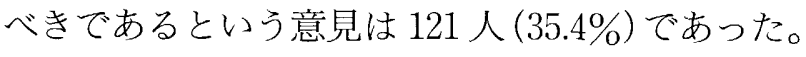
人事担当者がみてもよいと回答した者の率は、現 病歴 $46.9 \%$ 、自覚症状 $34.9 \%$ 、既往歷 $30.2 \%$ 、血压 27.1\%、血糖 18.1\%、喫煙歴 16.1\%、総コレステロー ル $14.4 \%$ 、体重 $13.3 \%$ 、家族歴 3.4\% と項目により 差があった。個人情報保護法への対応は、「委託先 との契約の確認と見直し」、「職場の個人情報保護 方針の公表」、「個人情報の取扱い責任者の明確化」 が過半数に達したが、「医療職が関与しにくい職場 の対応策の検討」、「診療と産業保健に関する健康 情報の区別」は 10\% 以下にとどまった(表)。対応 した時期は、ほとんぞの項目で、2003 年の個人情報 保護法の公布時ではなく、2005 年の同法の全面施 行時であった。

【考察】個人情報保護法が施行され、健康情報を取 扱う目的、医療職と非医療職の間での健康りスク のコミュニケーション、労働者の同意の取り方、健 康情報の保護と利用のバランスなどの課題が重要 となっている。

謝辞：本研究の一部は、文部科学省科研費 (c) 855 による助成を受けて実施した。

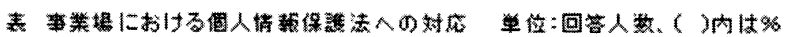

\begin{tabular}{|c|c|c|c|c|c|c|c|c|c|c|}
\hline \multirow{2}{*}{ 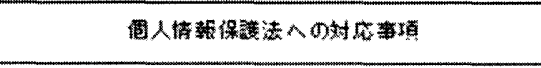 } & \multicolumn{4}{|c|}{ 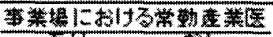 } & \multicolumn{4}{|c|}{ 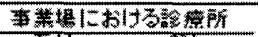 } & \multirow{2}{*}{\multicolumn{2}{|c|}{ 合 韩 }} \\
\hline & \multicolumn{2}{|c|}{ 6y } & \multicolumn{2}{|c|}{$2 t$} & \multicolumn{2}{|c|}{60} & \multicolumn{2}{|c|}{26} & & \\
\hline 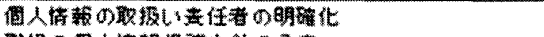 & 65 & $(57.5)$ & 117 & $(48.5)$ & 100 & $(54.1)$ & 82 & $(48.5)$ & 182 & $(51.4)$ \\
\hline 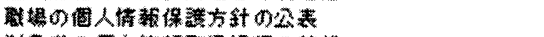 & 75 & $(66.4)$ & 128 & $(53.1)$ & 110 & $(59.5)$ & 33 & $(55.0)$ & 203 & $(57.3)$ \\
\hline 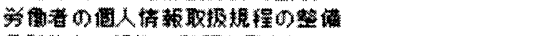 & 57 & $(50.4)$ & 97 & $(40.2)$ & 82 & $(44.3)$ & 72 & $(42.6)$ & 154 & $(43.5)$ \\
\hline 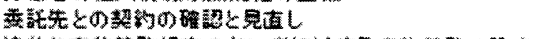 & 61 & $(540)$ & 150 & $(62.2)$ & 108 & (58.4) & 103 & $(60.9)$ & 211 & $(59.6)$ \\
\hline 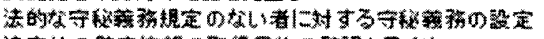 & 26 & $(23,0)$ & 38 & $(15.8)$ & 37 & $(20.0)$ & 27 & $(16.0)$ & 64 & $(18.1)$ \\
\hline 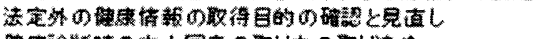 & 41 & $(36.3)$ & 85 & $(35.3)$ & 66 & $(35.7)$ & 60 & $(35.5)$ & 126 & $(35.6)$ \\
\hline 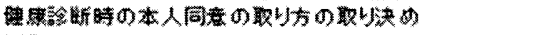 & 35 & $(48.7)$ & 106 & $(440)$ & 88 & $(47.6)$ & 73 & $(43.2)$ & 161 & $(45.5)$ \\
\hline 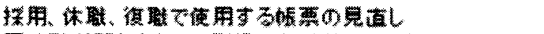 & 21 & $(18.6)$ & 34 & $(14.1)$ & 33 & $(19.8)$ & 22 & $(13.0)$ & 55 & $(15.5)$ \\
\hline 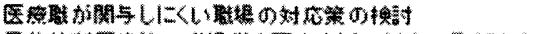 & 8 & $(7.1)$ & 10 & $(4.1)$ & 11 & $(5.9)$ & 7 & $(4.1)$ & 18 & $(5.1)$ \\
\hline 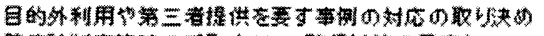 & 31 & $(27.4)$ & 44 & $(18.3)$ & 42 & (22.7) & 33 & $(195)$ & 75 & (21.2) \\
\hline 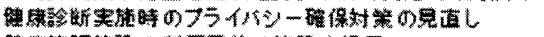 & 42 & $(37.2)$ & 63 & $(26.1)$ & 61 & $(33.0)$ & 44 & (260) & 105 & $(297)$ \\
\hline 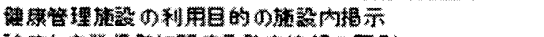 & 26 & $230)$ & 27 & $(112)$ & 32 & $(17.3)$ & 21 & $(12.4)$ & 53 & $(150)$ \\
\hline 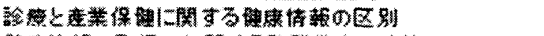 & 15 & $(13.3)$ & 17 & $(7.1)$ & 24 & $(13.0)$ & 8 & $(4.7)$ & 32 & (9.0) \\
\hline 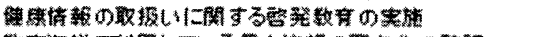 & 31 & $(27.4)$ & 34 & $(14,1)$ & 41 & $(22.2)$ & 24 & $(14.2)$ & 65 & $(18.4)$ \\
\hline 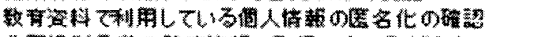 & 19 & $(168)$ & 28 & $(11.6)$ & 26 & $(14.1)$ & 21 & {$[12.4]$} & 47 & $(13,3)$ \\
\hline 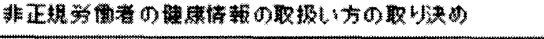 & 21 & $(186)$ & 27 & $(11.2)$ & 32 & $(17,3)$ & 16 & 195 & 48 & $(13.6)$ \\
\hline 弇 部 & 113 & $(1000)$ & 241 & 010001 & 185 & $(1000)$ & 169 & 1000 & 354 & $(1000)$ \\
\hline
\end{tabular}

